\title{
Luteinizing Hormone Measurement
}

National Cancer Institute

\section{Source}

National Cancer Institute. Luteinizing Hormone Measurement. NCI Thesaurus. Code C74790.

The determination of the amount of luteinizing hormone present in a sample. 